\title{
Influence of Environment on Learning Improvement and Student Characters Strengthening in Covid-19 Pandemic
}

\author{
Uci Dwi Cahya ${ }^{1]}$, Farahdiba Thahura $^{2]}$, Meylia Sari ${ }^{3]}$ \\ Universitas Sains Cut Nyak Dhien \\ Email: ${ }^{11}$ uciedwicahya88@gmail.com \\ ${ }^{2]}$ farahdibatahura@gmail.com \\ ${ }^{31}$ meyliasari78@gmail.com
}

\begin{abstract}
As a result of the Covid-19 pandemic, it has greatly impacted the world, especially in the field of education, therefore, with increasingly developing technological capabilities, the teaching and learning process in schools is also carried out online. This study aims to analyze the character values of students, as well as describe the design of student character learning in accordance with Pancasila as the basis of the State, and students are able to instill character values in everyday life. This research was conducted at MI TerpaduTahfidz Al Mubarak Langsa in grades 3 and 4 with 20 students per class, and $4^{\text {th }}$ grade teachers. The data analysis method used is a qualitative method by applying field research, namely by field observations, by observing each object which is done online through a video call application. From the results of the analysis, it was known that the character of students in grades III and IV of Integrated MI Tahfidz Al Mubarak 80\% is very in accordance with the values of Pancasila because the learning system is carried out always under the supervision of parents and teachers with a maximum number of ten students in one online class. In one class there are two teachers who teach in each class, every day parents must send reports on student progress to their respective class teachers. This is also inseparable from the role of parents in educating their children at home even though the state of the teaching and learning process is carried out online.
\end{abstract}

Keywords: Environment, Learning Improvement, Student Characters

\section{Pengaruh Lingkungan terhadap Peningkatan Belajar dan Penguatan Karakter Siswa di Masa Pandemi Covid-19}

\begin{abstract}
Abstrak
Akibat dari pandemic Covid-19, sangat berdampak pada dunia khususnya dibidang pendidikan, oleh sebab itu dengan kemampuan teknologi yang semakin berkembang maka proses belajar mengajar disekolah juga dilakukan secara online. Tantangan terbesar yaitu anak akan lebih sering berada dilingkungan social nya maka guru harus terus membimbing anak untuk membentuk kharakter anak walaupun dengan kondisi sekolah secara online. Penelitian ini bertujuan untuk menganalisis nilai karakter siswa, serta mendeskripsikan
\end{abstract}


desain pembelajaran karakter siswa yang sesuai dengan Pancasila sebagai dasar Negara, dan siswa maтри menanamkan nilai karakter dalam kehidupan sehari-hari. Penelitian ini dilaksanakan di MI Terpadu Tahfidz Al Mubarak langsa kelas 3 dan 4 dengan jumlah siswa per kelas 20 orang, dan guru kelas 4 orang. Metode analisis data yang digunakan adalah metode kualitatif dengan menerapkan penelitian lapangan yaitu dengan observasi lapangan, mengamati setiap objek yang dilakukan secara online melalui aplikasi video call, wawancara mendalam dan mendeskripsikan hasil analisis, yang kemudian akan diklasifikasikan berdasarkan urutan nilainya. Dari hasil analisis diketahui bahwa karakter siswa kelas III dan IV MI Terpadu Tahfidz Al Mubarak 80\% sangat sesuai dengan nilai-nilai Pancasila karena system pembelajaran dilaksanakan selalu dalam pengawasan orang tuadan guru dengan jumlah maksimal sepuluh siswa dalam satu kelas online. Didalam satu kelas terdapat dua guru yang mengajar di setiap kelas, setiap harinya orang tua harus mengirim laporan perkembangan murid kepada guru kelasnya masing-masing. Hal ini juga tidak terlepas dari peran orang tua dalam mendidik anaknya di rumah walaupun keadaan proses belajar mengajar dilakukan secara online.

Kata Kunci: Lingkungan, Peningkatan Pembelajaran, Karakter Siswa

\section{INTRODUCTION}

Environment is a place where a person will meet other people and carry out activities for their survival (Santika: 2020). The environment is everything that surrounds the individual throughout his life, the environment is divided into two types, namely the physical environment and the psychological environment.

The period of child development is a very important and critical period in human life and has a major impact on life. Teaching children to recognize the environment from an early age is very important, but parents must always choose a good environment for their children. The environment has a very big influence on the growth and development of children and children's personality.

Education units face enormous challenges in educating the younger generation to become intelligent and responsible generations. In addition to equipping the younger generation with basic academic knowledge and skills, educational units face the challenge of creating a positive learning environment as one of the determining factors for the effectiveness of teaching and learning activities and supporting factors for improving learning achievement. Considering the magnitude of the influence of the learning environment on the learning process and achievement, an appropriate assessment model is needed to photograph/obtain a picture of the learning environment in each educational unit. Another challenge faced by educational units is the formation of the character of students.

Children's behavior in the era of globalization is getting worse due to increasingly free and uncontrolled relationships, more and more criminal acts and crimes committed by school-age children, this is due to a lack of knowledge about morals and morals so that religious education is also needed that can be used as a place for formation of children's character. Character education in children must be designed and managed in such a way that in the learning process there is also the formation of good attitudes and behavior (Anshori: 2017). 
To support the implementation of character education can be carried out by means of learning activities both intracurricular and extracurricular. The school is a place where the teaching and learning process takes place which certainly occurs in the school environment. The influence of the school environment can have a negative impact on the development of students if a teacher does not know the character of each student.

Student social interaction will create a harmonious relationship. The forms of good social interaction can be seen by the existence of a cooperation, mutual respect and mutual respect. Cooperation will be created if in the learning process a problem is found, students will be happy to interact with each other by discussing and helping each other to solve problems that occur in the learning process.

An area or place of residence for social interaction is often referred to as the environment. The social environment is a place where a person lives to carry out social interactions in his environment. The social environment is divided into three, namely the family environment and school environment, and the environment of their playmates (Hariyanto: 2013). At that age children experience many demands and also pressure from the surrounding environment which can cause problems that they must face.

Social environment is one of the main factors that can influence a person to be able to take action and also change a person's behavior. The social environment is the surrounding community such as neighbors, friends, and also other people around them who are not yet known. The social environment plays the most important role in the formation of children's character. One's personality reflects one's behavior. A person's behavior can be distinguished from his personality because personality is the background of the behavior that exists in a person.

Social environment can be said as a means for someone to interact with other people and can shape personality and influence a person's behavior. Therefore, a good social environment will form a good personality as well; otherwise a bad social environment will form a bad personality.Students in Indonesia are expected to have a character profile of Pancasila students (Kemendiknas: 2010). In an effort to shape the profile of Pancasila students, the government has launched a character strengthening program at every level of education. A well-structured and well-implemented character education program can be an effective way to build students' character.

The someone habits that are carried out daily continuously in everyday life without realizing it greatly affect a person's life in the future. So that it will affect the character that is in a person. If the environment is good it will have a good effect on a person's character, otherwise if the environment is not good then this will create a character that is not good for a person.

This is what greatly affects the character of each person, a character that has been formed since childhood or when he was a child it will be very difficult to change it because it is ingrained so it takes time and hard work to change it. School is a secondary environment for children, in general children spend about 7 hours in school, and almost a third of the time children have is spent in school so that teachers and schools can have a good environmental influence for children (Sarwono: 2013).

Environment is one of the most influential factors for education 
(Ni'mawati, dkk: 2020). The environment affects the development of the child's character if it grows and develops in a good, polite, and religious environment, the child will be formed into a good person as well. The family is the beginning of and closest to the child in the period of growth and development of the child while parents are the first role model. For that, parents must be role models for children, parents must maintain an attitude because it will be imitated by children. A good attitude to children will participate in instilling good habits at home, as well as by doing simple things, namely maintaining cleanliness, speaking in polite words, and teaching children to be obedient to worship. Good habits like this will be embedded in the child so that it will not disappear even though the child has grown up.

The better environment that affects student activities, the better the character formed in children. There are also a small number of children who experience changes in character from good to bad; this is caused by children who get along with bad environments. Because not all children have good character (Sadikin: 2020). There are opinions that say that the environment influences the formation of children's character, namely:

a. The duration of the influence obtained

b. Critical attitude in dealing with the influence and educational assistance provided

c. Influence place to work

The close relationship between families can make it easier for every parent to be able to instill the attitudes and behavior of every member of his family, especially children. This is because parents are the first teachers for children, the roles and responsibilities of parents are very large and must be carried out in order to direct and guide children so as not to do things that are not good.

As for the forms of social interaction that are not good by children, we can see where students hate each other, drop each other, and the formation of peer groups where this will make each other to attack so as to create a relationship that is not harmonious. Bad social interaction will also create an uncomfortable learning atmosphere, this will hinder the learning process so that it often creates a noisy learning atmosphere.

The purpose of education is to lay the foundation for children's intelligence, knowledge, personality, noble character, and skills to live independently and attend further education. Based on this, the purpose of providing education is a very noble thing, namely laying a strong foundation for students to become human beings who have this. Therefore, the educational process carried out must be able to realize the character of students who are better and dignified.

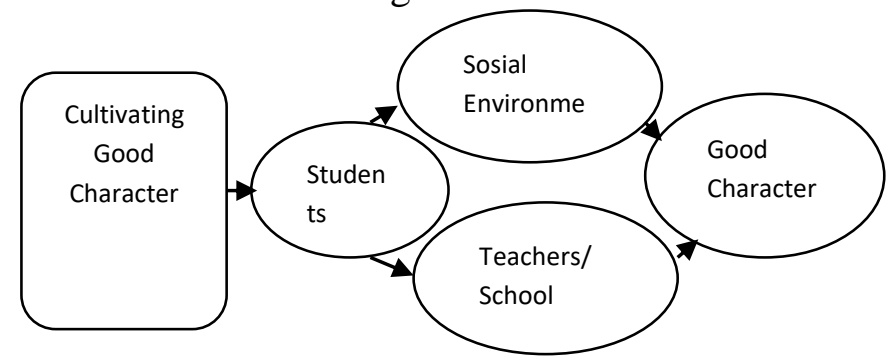

Figure 1. Motivation Process

Based on the chart above, if character education is carried out with certain principles and a strong commitment from the teacher and the community, it will affect the child's personality so that the creation of good character in children.

\section{METHOD}

In this research is qualitative method. The qualitative pattern aims to observe the subjects, interact with them, while the type 
of research used is descriptive research. Descriptive research provides a clear picture of a situation without any treatment of the object under study.

The researcher acts as a full observer and supervises the object of research carried out at MI TerpaduTahfidz Al Mubarak by involving grade 3 and 4 students. The researcher conducted direct interviews with the class teacher as the research subject. During the research process, the classroom teacher must know the presence of the researcher.Data collection techniques were carried out by means of field observations, indept interviews, and documentation. The purpose of some of the data collection techniques that researchers do is to find the data needed as a reference material for researchers to conduct research which later on the data will be analyzed by performing identification, classification and interpretation techniques so as to find the analysis of research results as expected.

Human instrument is an instrument in qualitative research that aims to be able to ask questions, analyze, photograph, and construct social situations that have been studied to be clearer and more meaningful, so researchers must equip themselves with theories and broad insights.

\section{FINDINGS AND DISCUSSION}

Based on the analysis of data that has been collected through field observations, interviews, and reviewing documents, the character of children who spend a third of their time in the school environment tends to be better. This is due to the good influences given by the school environment and also teachers to children. Based on research that $85 \%$ of school children are influenced by a good environment so that they have good character as well.
Intrinsic factors, namely factors from the school environment, including the role of the teacher, are the most basic things that affect the character of children, as well as school friends (Narwati: 2020). This is based on the time that a third of the children spend in the school environment. While extrinsic factors are factors from the parents' environment and the home environment.

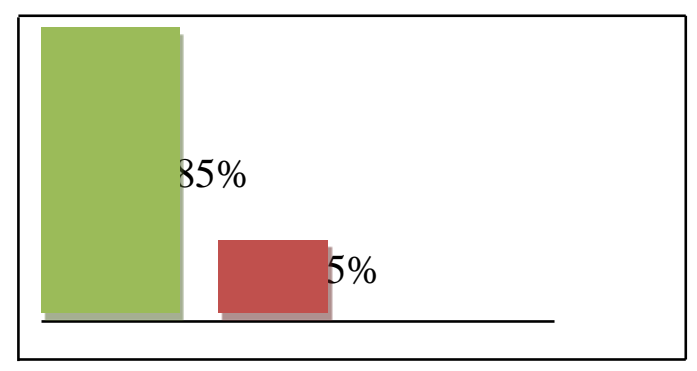

Instrinsic factors

Ekstrinsik factors

Figure 2. Social Environment Level

Both of these variables contribute to the formation of children's character. This means that there is a significant influence between the school environments on the formation of children's character. So far, problems regarding the character of children have received less serious attention from schools and teachers, so that the formation of children's character is not directed. To overcome this, serious efforts and efforts are needed from schools and teachers.

Data were obtained from various sources, using various data collection techniques, and were carried out continuously until the data were collected. There needs to be a record that is carried out in detail and in detail, this is because the data obtained from the field is very large.

The factors that have a significant influence on the formation of children's 
character are the environment in which children grow and are raised in the norms of family, friends, and social groups. Children have enough time to be in the school environment or outside of school with their friends.

Based on the results of data analysis, it was showed that from the number of 40 children who became the research sample, it was obtained that $85 \%$ had good characters. Then the results of the value obtained from the influence of the environment on the formation of children's character with a value of $85 \%$ greater than $15 \%$ of children who have bad characters.

A person cannot help others if he cannot help himself. It's the same with parents who want to grow character in their children. If you want your child to have a positive character, then parents must have a positive character too. This means that parents are required to apply moral values in their daily lives and treat children according to these moral values, not just telling them what to do and what not to do. Basically, it is easier for children to learn based on observations, not just from words.

Early childhood is a golden age for children, which means it is the best period in the learning process that only happens once and will never happen again. The growth and development of children at this age takes place very quickly and will be a determinant for the character of children in adulthood. Character building will be difficult to do, if the new parents do it when the child has entered adolescence. Children will develop healthy social relationships if they have feelings of worth, ability, and worthy of love. Every child needs attention, greeting, positive appreciation, and unconditional love so that children can develop all of their abilities well. From this experience, children will also treat others with love and care to treat others positively in accordance with the moral values they have acquired. Children will understand their friends and deserve to be appreciated, loved and cared for as they are.

Love for children does not mean parents are not allowed to reprimand their children if they do negative actions, but parents still have to give sanctions for negative actions they do. It's not the child's personality that makes parents angry, but one of the actions they do. Love is centered on the child's personality while discipline focuses on a particular behavior or attitude of the child.A person's relationship with his environment does not only run unilaterally, in the sense of the word only the environment that has an influence on the individual, the relationship between the individual and the environment there is a reciprocal relationship, namely the environment can affect the individual and the individual can affect the environment (Yoga: 2020).

Basically, humans have many and significant differences between one human and another, this of course can be influenced by daily attitudes or is the influence of the human heredity factor itself. And what often happens is that humans are distinguished by type of race, gender, physical characteristics, psychological/psychological traits, personality traits, innate talents and intelligence.

Of course, with all the differences that exist within humans, it becomes unique, but sometimes there are also many parties who misinterpret the differences that exist within each of them, not even infrequently because these differences can 
create disputes between humans themselves.

Sociopsychological factors are factors that influence a person's attitude due to psychological factors. Therefore we must understand the personality of each child but personality can be changed if one continues to be in a good environment.

Learning environment needs to be designed to support learning activities so that it can increase the comfort of individuals who occupy the environment to carry out learning activities (Salim: 2013).

Furthermore, learning environment is a means for students to devote themselves to activities, to be creative, until they get a number of new behaviors from their activities. In other words, the learning environment can be interpreted as a "laboratory" or a place for students to explore, experiment and express themselves to get new concepts and information as a form of learning outcomes. The learning environment has a major influence on the learning process and achievement, therefore an appropriate assessment model is needed to describe the learning environment in the education unit.The Environment has divided into two they are:

a. Physical environment

The physical environment is an environment in the form of nature, such as soil conditions, seasons and so on. Different physical environment will affect individual development. The physical environment will determine the comfort of individuals in carrying out their activities, if the environmental conditions where they live have fertile soil conditions, fresh air will affect the individual.

b. Social environment

The social environment is a community environment that causes interactions between individuals with one another. The state of society will more or less affect the development of individual characteristics. The social environment is divided into two, namely the primary and secondary social environments (Salmet: 2011).

The primary social environment is the social environment in which there is a close relationship between members of the community with one another. People who have such close relationships are natural if they have the potential to affect the nature of individuals in society. The closer the relationship with the community, the more profound it will be. In secondary social, there are two types of stages, namely resocialization which is where a person is given a new self-identity, while desocialization is a stage where each individual will accept a new self-identity and delete the old one. From the process of these two stages, there are several individuals in the same situation, separated from the wider community for a certain period of time and formally regulated.

This is a process that takes place throughout human life, starting from childhood to continuing after childhood into a new sector of the objective world of society. In formal institutions, secondary socialization is exemplified such as not littering, or participating in social life. This activity allows the community to mingle with one another. It also makes the community closer in togetherness, so as to create overall social interaction.

Research on education and character strengthening has grown rapidly. This is something that needs to be appreciated. When many educators agree that strengthening character education should be encouraged, it is not just a slogan. This research is expected to provide an appropriate assessment method to obtain an overview of the learning environment 
that is able to support the implementation of character education and can also examine effective character education programs to be implemented in Indonesia.

Character is the quality or mental or moral strength, morality or character of an individual which is a special personality that distinguishes it from other individuals. Meanwhile, character education is the deliberate effort to help people understand, care about, and acts upon core ethical values, which in this case contain three aspects, namely knowledge, heart/feel and actions based on the values that are the reference.An education character is currently the most important part of education in Indonesia. When people are treated to recordings of Indonesian people's behavior every day that are far from the values of the Indonesian character who are gentle, polite, friendly, and uphold eastern culture, character education is the spearhead of improving this situation. Character education is a means of laying back the noble values of the nation.

The nature of character education actually aims to instill values and attitudes and good behavior as an effort to shape the character of students in schools. The main purpose of character assessment is not to give value to the character of students, but to obtain information about the extent to which the character development of students. Thus, efforts to develop or strengthen the right character can be taken.

The Ministry of National Education has conducted participatory research on the implementation of character education conducted in various educational units and superior schools in several provinces. From early childhood education units, basic education, and advanced levels, as well as education units for children with special needs. This research resulted in various ways and methods of implementing character education which were put together in a book entitled Guidelines for Implementation of Character Education (Based on Experience in Pioneer Education Units).

Determined that values developed in cultural education and national characters are identified from the following four sources, namely religion, Pancasila, culture and national education goals (Dadang: 2020).To support the character education process, educators and school members provide concrete examples and exemplary values in the learning process in the classroom and outside the classroom within the school environment, through learning and discussion processes, observation of model behavior, and problem solving practices that include take these values into account.

The younger generation with basic academic knowledge and skills, education units faces the challenge of creating a positive learning environment as one of the determining factors for the effectiveness of teaching and learning activities and supporting factors for improving learning achievement. Considering the magnitude of the influence of the learning environment on the learning process and achievement, an appropriate assessment model is needed to photograph/obtain a picture of the learning environment in each educational unit.

Part from the environment, character education is also the spearhead of improving this situation. Character education is a means of laying back the noble values of the nation (Hanna: 2020). To support the character education process, educators and school members must provide concrete examples and examples through values in the learning process in 
the classroom and outside the classroom in the school environment, through the learning process and discussion, observation of model behavior, and problem-solving practices that include and consider these values. In other words, the learning environment can be interpreted as a "laboratory" or a place for students to explore experiment and express themselves to get new concepts and information as a form of learning of learning outcomes.

Character education aims to equip children to have the ability to distinguish between good and bad, right and wrong so that they are able to uphold the values of truth. Character education aims to form a complete human being with character that is able to develop optimal physical, emotional, social and spiritual aspects (Majid: 2011). Once grown in good character, children will grow with the capacity and commitment to be able to do the best things and do everything right, and tend to have a purpose in life.

The function of the school is to help families in the education of children in schools to be able to provide knowledge, skills and attitude values as a whole in accordance with what is needed by children. There are several factors that can affect the formation of children's character in the school environment, among others: bad teacher teaching methods will affect children's learning, because what the teacher conveys will be recorded by the child and will be imitated and then done by the child. Teachers should use the right method when teaching so as to increase children's motivation to learn which can have an impact on the formation of a better child's personality.

A teacher is someone who has knowledge, teaches his knowledge to others, so that that person has an increase in the quality of human resources and also an increase in the field of science. There are several tasks that a teacher has, namely: as a teacher who has the task of planning and implementing the teaching process that has been prepared, and providing value to students after the learning process is complete(Annisa: 2020). Then the teacher as an educator is to provide direction to students regarding personality. And the last is the teacher as a leader, which means the teacher is in charge of leading and controlling the series itself, students, and also the community.

Character has the meaning of how to think and behave each individual to work together both in the family environment and also in society. Establishing an independent character means the process of shaping one's personality to behave well in accordance with the rules that exist in society. Character is likened to a stamp and also the characteristics inherent in a person. Characters can be formed in different meanings because characters contain innate elements. Character is strongly influenced by external factors.

Distance learning or online is a learning process that is chosen to provide learning to students who are unable to carry out the face-to-face learning process due to the COVID-19 pandemic situation. Through online learning creates a modern learning process that uses the internet network that is useful for bringing up learning interactions.

The management of character education can be developed by being taught, accustomed, and trained to be consistent which will later become character and become culture (Sudrajat: 2011). Character education during the pandemic can be collaborated with parents; parents of students cannot fully carry out character education for their children without the help of teachers. Parents 
believe that teachers really help them in shaping and building children's character. Without the role of the teacher, parents will not be able to optimally shape and build the character of their children.

We can all learn from the covid-19 pandemic that teachers and parents must work together to build education. Besides, the role of the teacher is currently being replaced by parents to guide and teach discipline during the learning process. Parents should motivate children and make themselves good facilitators for children in learning (Zainal: 2020). Especially in character education during the pandemic, parents are one of the most dominant and main roles for children. Making independent children is much more valuable so that they can grow strong and resilient characters. Parents have facilitators in accompanying their children while studying at home, especially in building children's character.

In order to achieve some of the things above, teachers can set an example by creating biased learning content through YouTube, Instagram and others. This can provide great benefits for students during learning because the material provided by the teacher can be seen repeatedly. By looking at the example obtained from the teacher, children will be accustomed to using ICT media in the learning process.

This responsibility character value will later be the gate to open other children's character values when applied in learning (Widyanuratikah: 2021). Thus there are no obstacles that occur in the process of learning character to children which is carried out online. This makes the child unsaturated due to the awakened responsibility and motivation in obtaining solutions to the problems they face.

Psychologically, the environment plays an important role in the behavior of children, especially schools, because that is where children are given continuous treatment so that children are expected to change their behavior as expected. Schools have provided a supportive environment for educational success, so schools directly provide a touch for children.

The elements in the formation of children's character are the mind because the mind in which there are all programs formed from life experiences. This will then form a belief system that can eventually form a mindset that can influence children's behavior. When children enter school, they experience many changes in their self-concept. Among them there may be those who feel themselves stupid and in the end they despair (Siahaan: 2020).

The negative impact of concepts like this can make children feel less confident and difficult to develop in the future. Schools are responsible not only for creating a generation that excels in the field of science, but also for discovering the identity, character, and personality of the child.

Efforts to form children's personalities in schools, through character education must be accompanied by value education with rules for applying a modeling approach, namely to socialize and familiarize the school environment to revive and enforce correct moral and moral values through good examples.

\section{CONCLUSION}

From the results of research on influence of environment on learning improvement and students characters strengthening in the covid-19, it can be concluded that the influence of the social environment that can affect changes in children's behavior is from the family 
environment. A harmonious family environment and always educating their children well will produce a good child's personality too, a child who has a bad personality due to a bad family environment will affect the child's personality to socialize with the surrounding environment.

Schools have implemented character education, namely through the development of the 2013 curriculum (K13). Besides that, character education also takes place naturally through the relationship between teachers and children, although this is not included in the school curriculum. The school environment is designed to effectively provide a number of activities that take place in schools based on character education so as to produce children who have good character so that the school's goals can be realized, namely creating the next generation of people who are smart and also have good character.

Education that develops character is a form of education that can help develop morals and responsibility in children and provide affection by showing and teaching good character. This is a long-term effort that leads to morals, ethics and children's education which is a concern as well as an increasing concern in society. Children can judge what is right and wrong and do what they believe. The educational environment is an effective way to shape children's character by making basic ethical values the basis of education, namely using a sharp, proactive and effective approach in building and developing children's character by creating a caring community in the family, school and community.

\section{REFERENCES}

Abidin, Zainal. (2020). Efektivitas Pembelajaran Jarak Jauh Pada Masa Pandemi Covid-19. Research and Development. Journal of Education.

Annisa, Nurul, Miftah. (2020) Pentingnya Pendidikan Karakter pada Anak Sekolah Dasar di Zaman serba Digital. Jurnal Pendidikan Sains.

Anshori, I .(2017). Penguatan pendidikan Karakter di Madrasah. Halaqah: Islamic Education Journal, 1 (2), 11.

Balitbang Puskur. (2010). Pengembangan Pendidikan Budayadan Karakter Bangsa. Jakarta. Kemdiknas Balitbang Puskur.

Basuki, Slamet. (2011). Pendidikan Karakter dalam Perspektif Teoridan Praktek. Eprints UNY: Yogyakarta.

Dirjen Dikdasmen. 2010. Model

Pembinaan Karakter di Lingkungan Sekolah. Jakarta. Kemdiknas.

Hariyanto. (2013). PendidikanKarakter: PT. Remaja Rosdakarya.

Irfanti,Inka, Hanna. (2020). Strategi Guru dalam Membentuk Karakter pada Anak di RA Ma'arif Pulutan Salatiga. IAIN Salatiga.

Majid, Abdul. (2011). Pendidikan Karakter Perspektif Islam: Remaja Rosda Karya.

Narwati, Sri. (2011). Pendidikan Karakter. Familia: Yogyakarta.

Ni'mawati, Handayani, F., Hasanah, A. (2020). Model Pengelolaan Pendidikan Karakter di Sekolah pada Masa Pandemi. 
Fastabiq: Jurnal Studi Islam.

Vol 1, No 1.

Prastowo, A. (2012). Metode penelitian

Kualitatif dalam Perspektif

Rancangan Penelitian.Ar-

ruzzmedia. Yogyakarta.

Sadikin, Ali. (2020). Pembelajaran

Daring di Tengah Wabah

Covid-19. Biodik: Jurnal

Ilmiah Pendidikan Biologi.

Santika, I.W.E. (2020), Pendidikan

Karakter Pada Pembelajaran

Daring. Indonesian Values and

Character Education Journal, Vol. 3, No 1.

Sarwono, S.W. (2013). Psikologi Remaja. Rajagrafindo Persada: Depok.

Salim, Moh. (2013). Pendidikan Karakter

(Konsepsi dan

Implementasinya Secara

Terpadu di Lingkungan

Keluarga, Sekolah, Perguruan

Tinggi, dan Masyarakat). Ar-

Ruzz Media: Yogyakarta.

Siahaan, Matdio. (2020). Dampak Pandemi Covid-19 Terhadap Dunia Pendidikan. Jurnal Kajian Ilmiah, Vol. 1, No. 1.

Sudrajat, Ajat. (2011). Mengapa Pendidikan Karakter?. Jurnal Pendidikan Karakter, Vol 11, No 1.

Suwendra, I Wayan. (2018). Metodologi Penelitian Kualitatif dalam Ilmu Sosial Pendidikan, Kebudayaan, dan Keagamaan. Nilacakra: Bali.

Widyanuratikah, Inas, dan Nora Azizah, (2021), Pendidikan Karakter Tak Boleh Lepas Selama PJJ, diakses dari www.republika.co.id. $\quad 25$ Agustus 2021, pukul 20.00. 